\title{
Discrimination of $\mathrm{TiO}_{2}$ polymorphs in sedimentary and metamorphic rocks
}

\author{
Silke Triebold • George Luiz Luvizotto • \\ Raimon Tolosana-Delgado • Thomas Zack • \\ Hilmar von Eynatten
}

Received: 10 February 2010/ Accepted: 29 June 2010/Published online: 13 July 2010

(C) The Author(s) 2010. This article is published with open access at Springerlink.com

\begin{abstract}
Investigation by Raman spectroscopy of samples from different geological settings shows that the occurrence of $\mathrm{TiO}_{2}$ polymorphs other than rutile can hardly be predicted, and furthermore, the occurrence of anatase is more widespread than previously thought. Metamorphic pressure and temperature, together with whole rock chemistry, control the occurrence of anatase, whereas variation of mineral assemblage characteristics and/or fluid occurrence or composition takes influence on anatase trace element characteristics and re-equilibration of relict rutiles.
\end{abstract}

Communicated by T. L. Grove.

Electronic supplementary material The online version of this article (doi:10.1007/s00410-010-0551-x) contains supplementary material, which is available to authorized users.

S. Triebold $(\varangle) \cdot H$. von Eynatten

Abt. Sedimentologie und Umweltgeologie, GZG,

Universität Göttingen, Goldschmidtstr. 3,

37077 Göttingen, Germany

e-mail: striebo@gwdg.de

G. L. Luvizotto

Mineralogisches Institut, Universität Heidelberg,

Im Neuenheimer Feld 236, 69120 Heidelberg, Germany

Present Address:

G. L. Luvizotto

Max-Planck-Institut für Chemie,

Joh.-Joachim-Becher Weg 27, 55128 Mainz, Germany

R. Tolosana-Delgado

Departament d'Enginyeria Hidràulica, Marítima i Ambiental,

Universitat Politècnica de Catalunya, c/Jordi Girona, 1-3,

08034 Barcelona, Spain

T. Zack

Institut für Geowissenschaften, Universität Mainz,

Becher Weg 21, 55128 Mainz, Germany
Evaluation of trace element contents obtained by electron microprobe in anatase, brookite, and rutile shows that these vary significantly between the three $\mathrm{TiO}_{2}$ phases. Therefore, on the one hand, an appropriation to source rock type according to $\mathrm{Nb}$ and $\mathrm{Cr}$ contents, but as well application of thermometry on the basis of $\mathrm{Zr}$ contents, would lead to erroneous results if no phase specification is done beforehand. For the elements $\mathrm{Cr}, \mathrm{V}, \mathrm{Fe}$, and $\mathrm{Nb}$, variation between the polymorphs is systematic and can be used for discrimination on the basis of a linear discriminant analysis. Using phase group means and coefficients of linear discriminants obtained from a compilation of analyses from samples with well-defined phase information together with prior probabilities of groupings from a natural sample compilation, one is able to calculate phase grouping probabilities of any $\mathrm{TiO}_{2}$ analysis containing at least the critical elements $\mathrm{Cr}, \mathrm{V}, \mathrm{Fe}$, and $\mathrm{Nb}$. An application of this calculation shows that for the appropriation to the phase rutile, a correct-classification rate of $99.5 \%$ is obtained. Hence, phase specification by trace elements proves to be a valuable tool besides Raman spectroscopy.

Keywords $\mathrm{TiO}_{2}$ polymorph discrimination .

Phase classification - Anatase - Brookite - Rutile .

Erzgebirge $\cdot$ Zr-in-rutile thermometry

\section{Introduction}

In the last few years, the application of rutile trace element systematics as tracer for metamorphic and sedimentary processes (provenance analysis) received wide attention. Zack et al. (2004b) and Watson et al. (2006), refined by Tomkins et al. (2007) establish rutile thermometry based on the increasing incorporation of $\mathrm{Zr}$ with rising 
metamorphic temperature. Zack et al. (2004a) constrain concentration ranges for $\mathrm{Nb}$ and $\mathrm{Cr}$, which discriminate rutile deriving from pelitic or mafic source rocks. High $\mathrm{U}$ contents provide the opportunity to apply $\mathrm{U} / \mathrm{Pb}$ - or (U-Th)/ He dating techniques (e.g., Mezger et al. 1989; Vry et al. 2003; Vry and Baker 2006; Stockli et al. 2007). Further work addresses the applicability of the rutile thermometer (Spear et al. 2006; Zack and Luvizotto 2006; Triebold et al. 2007; Luvizotto and Zack 2009) and lithology discrimination using $\mathrm{Nb}$ and $\mathrm{Cr}$ contents (Triebold et al. 2007; Meinhold et al. 2008; Luvizotto and Zack 2009). It is found in different studies, that by inclusion of rutile in other mineral phases, $\mathrm{Zr}$ contents in rutile are inhibited from re-equilibrating during prograde (Spear et al. 2006) or retrograde (Zack et al. 2004b; Triebold et al. 2007) metamorphism and hence maximum $\mathrm{Zr}$ contents within a rock or sand sample should be used for thermometry.

Additionally to rutile, both brookite and anatase are likely to occur in any metamorphic and sedimentary environment. Older experimental results (e.g., Dachille et al. 1968; Jamieson and Olinger 1969) indicate that anatase and brookite are the low- $\mathrm{T}$ and low- $\mathrm{P} \mathrm{TiO}_{2}$ phases, being stable up to about $600^{\circ} \mathrm{C}$ at air pressure and $100^{\circ} \mathrm{C}$ at $2 \mathrm{GPa}$ (anatase) and up to about $700^{\circ} \mathrm{C}$ at air pressure and ca. $475^{\circ} \mathrm{C}$ at $0.8 \mathrm{GPa}$ (brookite). Above about $475^{\circ} \mathrm{C}$, rutile is the major stable phase. However, already Dachille et al. (1968), supported by new work (Grzmil et al. 2007; Sembaev et al. 2008) stress that whole rock composition plays an important role in the variation of the transition to rutile. Smith et al. (2009) found that the transition from anatase to rutile is thermodynamically favorable at all temperatures, and the formation of anatase requires lowtemperature aqueous conditions. At ultrahigh pressure conditions, $\mathrm{TiO}_{2}$ (II) $\left(\alpha-\mathrm{PbO}_{2}\right.$ structure) is stable (Withers et al. 2003). Hwang et al. (2000) find this phase included in garnet in the Erzgebirge.

In their crystal structures, rutile and anatase are the most similar $\mathrm{TiO}_{2}$ polymorphs, both crystallize in the tetragonal crystal system. The brookite crystal structure is orthorhombic. Common to all three polymorphs is their being built of $\mathrm{TiO}_{6}$ octahedra, which are connected among each other in different ways depending on the polymorph type: in rutile, each octahedron is connected to two, in brookite to three, and in anatase to four neighboring octahedra via its edges.

In this contribution, we will demonstrate that rutile $\mathrm{Cr} /$ $\mathrm{Nb}$ systematics and Zr-in-rutile thermometry cannot be applied to brookite or anatase. Thus, classification of $\mathrm{TiO}_{2}$ phases is necessary before applying these tools. This is especially valid for sedimentary provenance studies, where source rock paragenesis is usually not known, and thus, petrological constraints derived from single grains are important (e.g., Weltje and von Eynatten 2004). We will evaluate and introduce various ways of $\mathrm{TiO}_{2}$ polymorph discrimination of embedded single grains. Optical microscopy and scanning-electron microscopy (SEM) imaging, Raman spectroscopy and chemical composition by electron microprobe (EMP) have been explored.

\section{Sample description and geological setting}

We base our investigations on sand and rock samples from the Variscan Erzgebirge, as well as from two Mesozoic successions north of the Harz mountains (Warnstedt and Huy), which contain various amounts of rutile, anatase, and brookite. Sand samples from the Erzgebirge are stream deposits with small (up to $10 \mathrm{~km}^{2}$ ) catchment areas. Sampling locations for all samples are shown in Figs. 1 and 2. These samples derive from different geological settings ranging from sedimentary to metamorphic (up to $950^{\circ} \mathrm{C}$ and up to $4.5 \mathrm{GPa}$ ). They are compared to rutile, anatase, and brookite single crystals from various other locations (Table 1). Rutile analyses of samples from the Alps (Switzerland), Syros (Greece) and Mexico are only shown for comparison and will not be described in detail. A complete sample list for the Erzgebirge samples including location coordinates is given by Triebold et al. (2007).

Two samples from Mesozoic siliciclastic rocks are investigated to include anatase of clearly diagenetic origin. Sample HUY-1 is a lower Triassic quartz-rich sandstone (Buntsandstein) from the small Huy mountains range ca. $15 \mathrm{~km} \mathrm{~N}$ of the Harz and ca. $45 \mathrm{~km}$ WSW Magdeburg. Sample WAR-9 derives from a ca. $1.5 \mathrm{~m}$ thick layer of well-sorted fine sand in Upper Cretateous (Santonian) successions exposed in Warnstedt sand pit, which is located ca. $5 \mathrm{~km} \mathrm{~N}$ of the Harz and ca. $50 \mathrm{~km} \mathrm{SW}$ Magdeburg.

The Erzgebirge metamorphic complex is situated at the northwestern border of the Bohemian Massive in eastern Germany. It belongs to the Saxo-Thuringian zone of the central European Variscides. The Erzgebirge is characterized by a large-scale antiformal structure, intruded by posttectonic granitoids of late-Variscan age. It represents a stack of tectonic units resulting from continent-continent collision processes (deformation, metamorphism, and exhumation) during the Variscan orogeny (e.g., Willner et al. 1997, 2000; Rötzler et al. 1998; Mingram 1998).

The western Erzgebirge consists of a sequence of tectonometamorphic units with low- to high-grade PT-histories (up to at least $950^{\circ} \mathrm{C}$ and $4.5 \mathrm{GPa}$; Massonne et al. 1998). Following Triebold et al. (2007), these units are labeled, from tectonically lowermost to uppermost, the Cadomian Gneisses, Gneiss Unit (GU), Micaschist Unit (MU), Garnet-Phyllite Unit (GPU), Phyllite Unit (PU), and Ordovician Slates (OS). Additionally, three subunits, which have preserved earlier, higher PT-conditions, are defined: eclogite-rich Gneiss Units 1 (EGU1) and 2 
Fig. 1 Geological sketch of the Central European Variscides, modified after Dallmeyer et al. (1995). Locations for samples HUY-1 and WAR-9 are shown (north of Harz Mts). The rectangle indicates the position of the map in Fig. 2

(Erzgebirge). The small inset figure shows a political map of Europe with the location of the geological sketch marked by a rectangle

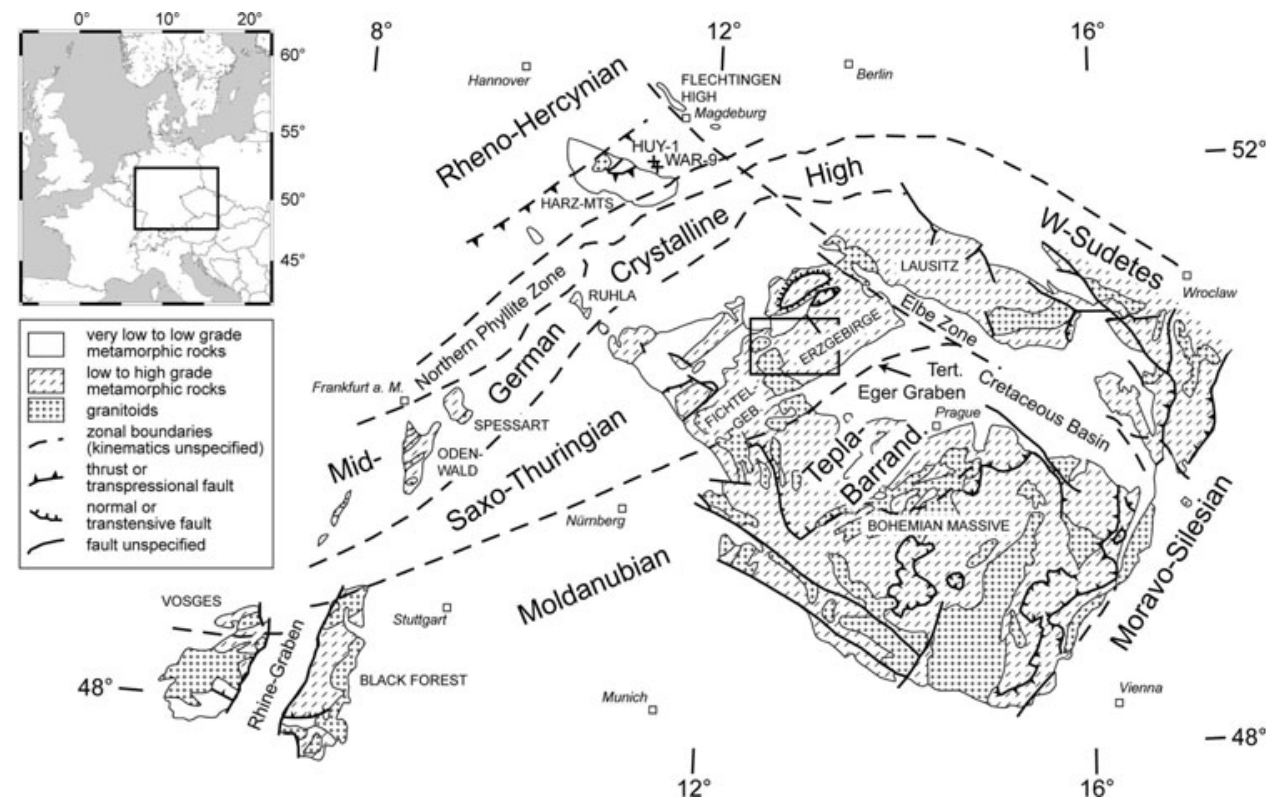

Table 1 List describing the localities of important samples used in this contribution (except Erzgebirge samples)

\begin{tabular}{|c|c|c|c|}
\hline Label & $\mathrm{TiO}_{2}$ Phase(s) & Sample type & Sample locality \\
\hline HUY-1 & Rt, Ant & Rock & Huy (Buntsandstein), Germany \\
\hline WAR-9 & Rt, Ant & Sand & Warnstedt sand pit (Upper Cretateous: Santonian), Germany \\
\hline GZG.MIN.4.4.36.6 & Brk & s.c. & Modriach, Steiermark, Austria \\
\hline GZG.MIN.4.4.36.22 & Rt & s.c. & Binntal, Wallis, Switzerland \\
\hline GZG.MIN.4.4.36.30 & Rt & s.c. & Binntal, Wallis, Switzerland \\
\hline GZG.MIN.4.4.36.116 & Rt & s.c. & Magnet Cove, Arkansas, USA \\
\hline GZG.MIN.4.4.36.141 & Rt & s.c. & Laora do Mato at Yequitinhonha, Brasil \\
\hline GZG.MIN.4.4.36.145 & Rt & s.c. & Boa Vista, Brasil \\
\hline GZG.MIN.4.4.36.153 & Rt & s.c. & St. Yrieux near Limoges, France \\
\hline GZG.MIN.4.4.36.165 & Rt & s.c. & Gamsberg, SW-Africa \\
\hline GZG.MIN.4.4.71.14 & Ant & s.c. & Tavetsch, Graubünden, Switzerland \\
\hline GZG.MIN.4.4.71.29 & Ant & s.c. & Cavradi Tavetsch, Graubünden, Switzerland \\
\hline GZG.MIN.4.4.71.44 & Ant & s.c. & Binnental, Wallis, Switzerland \\
\hline GZG.MIN.4.4.71.69 & Ant & s.c. & Alp Lercheltini, Binnental, Wallis, Switzerland \\
\hline GZG.MIN.4.4.71.79 & Ant & s.c. & Minas Gerais, Brasil \\
\hline GZG.MIN.4.4.71.94 & Ant & s.c. & quarry Petersberg near Halle, Sachsen-Anhalt, Germany \\
\hline GZG.MIN.4.4.79.29 & Brk & s.c. & Iseltal, Frigatten, Austria \\
\hline GZG.MIN.4.4.79.30 & $\mathrm{Rt}$ & s.c. & Magnet Cove, Arkansas, USA \\
\hline
\end{tabular}

Samples labeled "GZG.MIN..." derive from the Geowissenschaftliches Museum und Sammlungen der Universität Göttingen

Rt Rutile, Ant anatase, Brk brookite (according to Kretz 1983), s.c. single crystal

(EGU2), and likewise an eclogite-rich Micaschist Unit (EMU). A summary of the published $\mathrm{P}$ and $\mathrm{T}$ conditions of the best-preserved metamorphic stage in each unit and subunit is shown in Fig. 2.

Triebold et al. (2007) find high- $\mathrm{Zr}$ rutiles in the lowmetamorphic Erzgebirge units and interpret them to be inherited, relic rutiles, which have survived the Variscan metamorphic event. Only above a certain temperature (the
"550-600 ${ }^{\circ} \mathrm{C}$ boundary"), rutiles are completely equilibrated with unit metamorphic temperatures.

\section{Sample preparation and analytical methods}

From the sand- and crushed rock samples, rutile was extracted via sieving, heavy-liquid separation, magnetic 


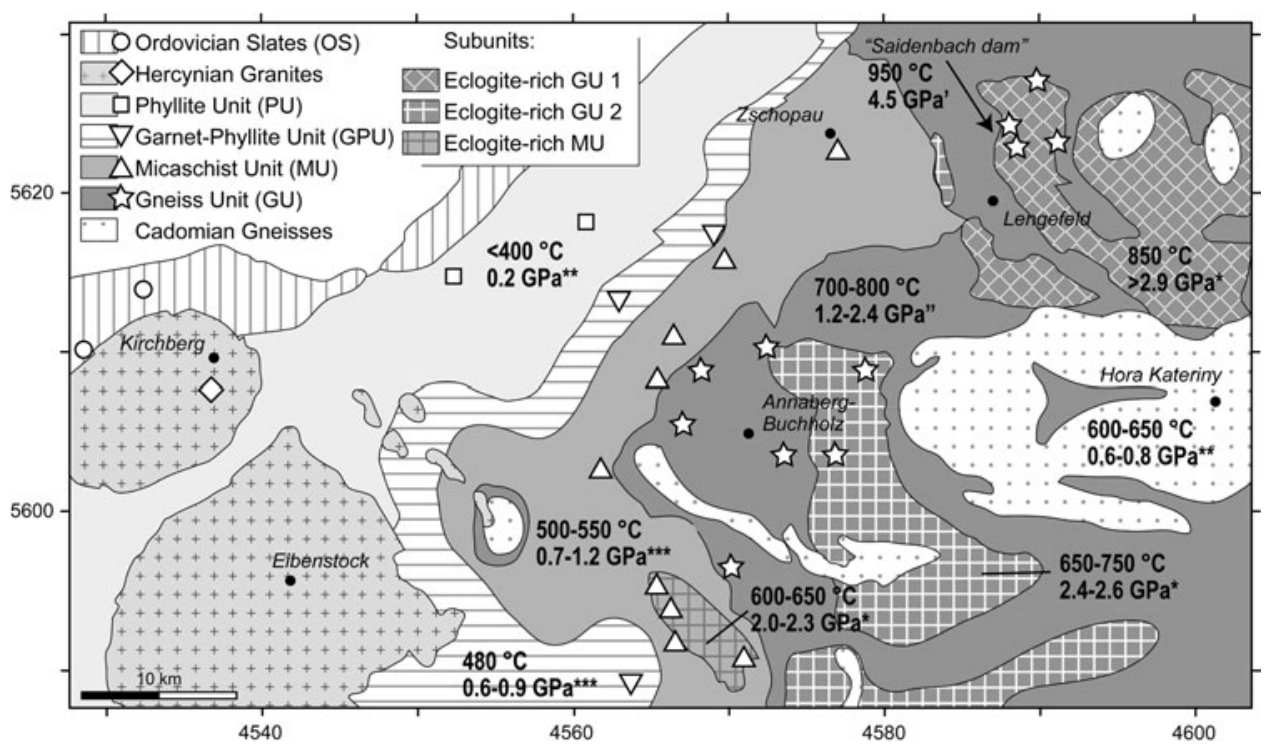

Fig. 2 Geological sketch of the western part of the Erzgebirge showing sampling locations. Samples from the same units are shown by similar symbols. The temperature and pressure estimates from preserved metamorphic assemblages are from: *Schmädicke and Müller (2000), **Mingram and Rötzler (1999), ***Rötzler et al.
(1998), 'Massonne et al. (1998), and "Willner et al. (1997). The coordinate grid is Gauss-Krüger (Potsdam). Compiled and redrawn from Willner et al. (1997), Mingram and Rötzler (1999), Schmädicke and Müller (2000), and geological maps of the Erzgebirge (1:25,000 and 1:200,000). Map slightly modified, from Triebold et al. (2007)

Table 2 EMP analysis conditions

\begin{tabular}{|c|c|c|c|c|c|c|c|c|c|c|c|}
\hline Element & $\mathrm{Ti}$ & $\mathrm{W}$ & $\mathrm{Nb}$ & $\mathrm{Si}$ & $\mathrm{Zr}$ & $\mathrm{Sn}$ & $\mathrm{Al}$ & $\mathrm{V}$ & $\mathrm{Cr}$ & $\mathrm{Mg}$ & $\mathrm{Fe}$ \\
\hline X-ray line & $\mathrm{K} \beta$ & $\mathrm{L} \alpha$ & $\mathrm{L} \alpha$ & $\mathrm{K} \alpha$ & $\mathrm{L} \alpha$ & $\mathrm{L} \alpha$ & $\mathrm{K} \alpha$ & $\mathrm{K} \alpha$ & $\mathrm{K} \alpha$ & $\mathrm{K} \alpha$ & $\mathrm{K} \alpha$ \\
\hline Counting time (s) & 30 & 200 & 300 & 150 & 300 & 200 & 150 & 200 & 200 & 150 & 150 \\
\hline BG time (s) & 15 & 100 & 150 & 50 & 150 & 100 & 50 & 100 & 100 & 50 & 50 \\
\hline $2-\sigma \mathrm{DL}(\mathrm{ppm})$ & 922 & 80 & 70 & 70 & 40 & 60 & 60 & 220 & 50 & 20 & 40 \\
\hline $2-\sigma$ error $(\mathrm{ppm})$ & 4,050 & 140 & 100 & 40 & 30 & 40 & 20 & 70 & 20 & & 20 \\
\hline
\end{tabular}

"Counting time" refers to the counting times on peak positions, "Background time" to the counting times on upper- and lower background (BG) positions. Errors and detection limits (DL) are median values calculated according to counting statistics

separation, and handpicking. As trace elements in rutile are not systematically related to grain size (von Eynatten et al. 2005), we focus on the grain size fraction having the highest percentage of rutile $(80-200 \mu \mathrm{m})$. Extracted separates, including the single crystals, were embedded in epoxy resin disks and polished. For EMP analysis, they were coated with carbon to ensure conductivity. Electron microprobe analyses were performed in Göttingen using a JEOL JXA 8900 instrument. Beam conditions were set to $25 \mathrm{kV}$ accelerating voltage and $80 \mathrm{nA}$ beam current. Matrix correction was performed using the $\Phi-\varrho-Z$ method (Armstrong 1995). All microprobe conditions, including counting times, errors and detection limits, can be reviewed in Table 2. No analysis obtained Mg above detection limit. $\mathrm{Si}$ was analyzed as indicator for phase mixture analyses. The extent of the influence of secondary fluorescence in adjacent silicates or silicate inclusions on the analysis result for Si is unclear. A couple of studies deal with the effect of the so-called "phase-boundary fluorescence" for other elements (e.g., Bastin et al. 1984a, b; Dalton and Lane 1996; Wark and Watson 2006). Our observations indicate that in most cases, $\mathrm{Si}$ concentrations do not derive from mixture analyses, but from secondary fluorescence effects (in silicate inclusions), which work over large distances (at least $50 \mu \mathrm{m}$ ).

Phase analysis was done using a confocal Raman spectrometer (Horiba Jobin-Yvon Labram HR 800 UV) with $633 \mathrm{~nm}$ laser excitation, $20 \mathrm{~mW}$ laser power, 1,200 lines/mm grating and a Peltier-cooled CCD detector. Because of the large number of crystals, automated single spot analysis was applied. Therefore, in most cases, phase information derives from one single measurement per crystal. Only for selected crystals where mixed spectra were obtained, more than one analysis was done and/or 
Fig. 3 Examples for Raman spectra from different samples and crystals. a-c Pure spectra of anatase, brookite, and rutile.

The most characteristic bands are labeled. d-f Mixed spectra between anatase and rutile
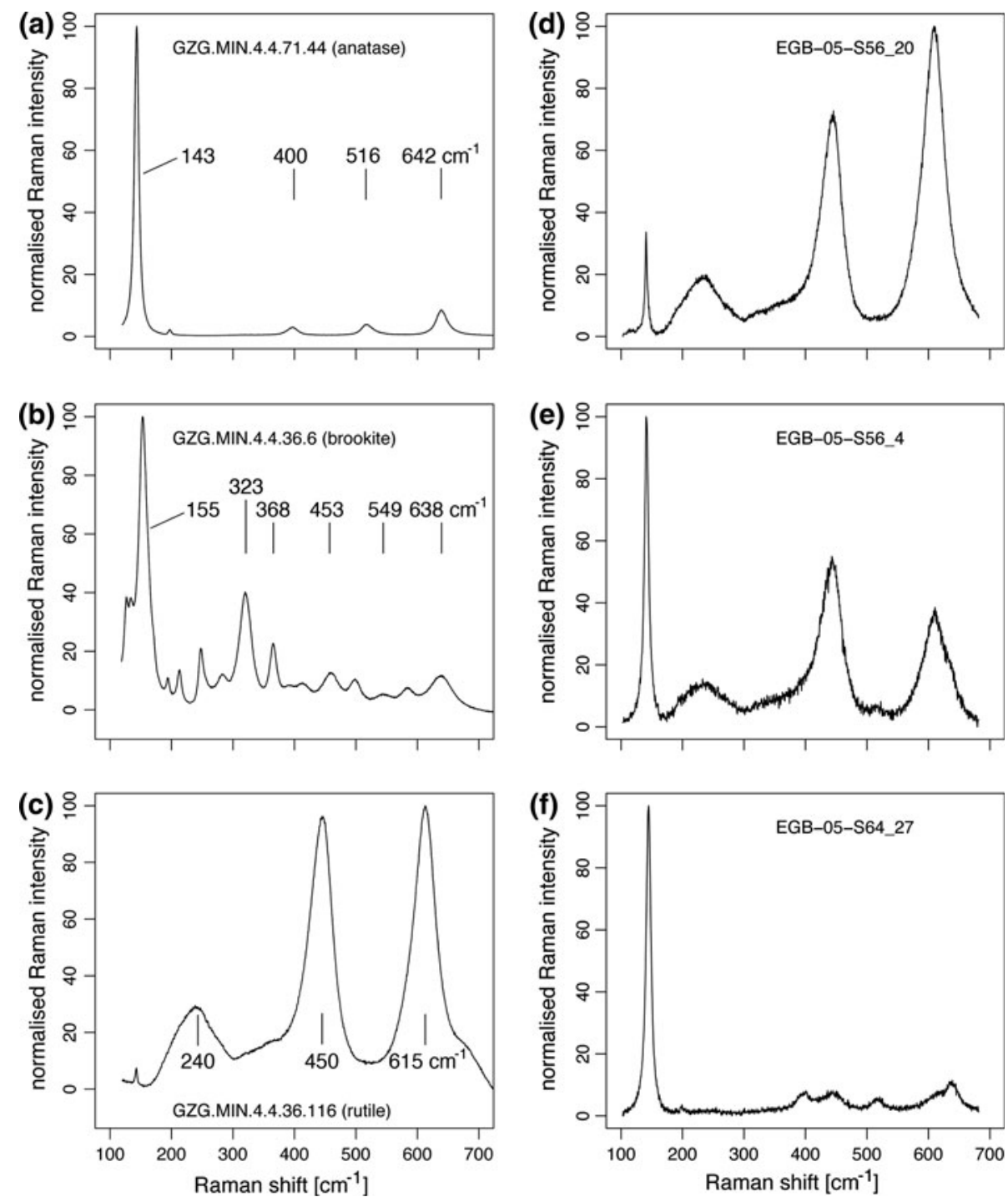

detailed mapping with $5 \mu \mathrm{m}$ increments was applied. In both single spot analyses and mappings, a $100 \times$ objective and a confocal hole of $200 \mu \mathrm{m}$ were used.

\section{Results}

\section{Raman spectroscopy}

The three $\mathrm{TiO}_{2}$ polymorphs rutile, anatase, and brookite can very well be distinguished. Rutile was identified by Raman bands at 240, 450, and $615 \mathrm{~cm}^{-1}$ (peak positions) and anatase by bands at 143, 400, 516, and $642 \mathrm{~cm}^{-1}$. Brookite produces a range of Raman bands with varying intensities, among these are bands at 128, 155, 215, 247, $250,289,323,368,453,549$, and $638 \mathrm{~cm}^{-1}$. A compilation of literature on $\mathrm{TiO}_{2}$ Raman spectra is given by Meinhold et al. (2008) and Luvizotto et al. (2009). Figure 3a-c show examples for pure rutile, anatase, and brookite spectra.

Erzgebirge polymorph statistics are complicated by the occurrence of mixture analyses between anatase and rutile with varying Raman band intensities of both polymorphs. Examples are shown in Fig. 3d-f. In all our samples, brookite was found only as pure phase. Where Raman analysis obtained a mixed spectrum, mapping was applied for examplary individuals (Fig. 4). It was found that mixed spectra are never homogeneously distributed in such "anatase-rutile intergrowth" (ARI) grains but occur as zones of up to $30 \mu \mathrm{m}$ in diameter or transition regions of up to $30 \mu \mathrm{m}$ in thickness between more or less pure anatase and rutile regions. Please note that we are using the term "intergrowth" only in its descriptive meaning, without genetical implications. With the Raman analysis settings used, a depth resolution of 3-10 $\mu \mathrm{m}$ and a lateral resolution 

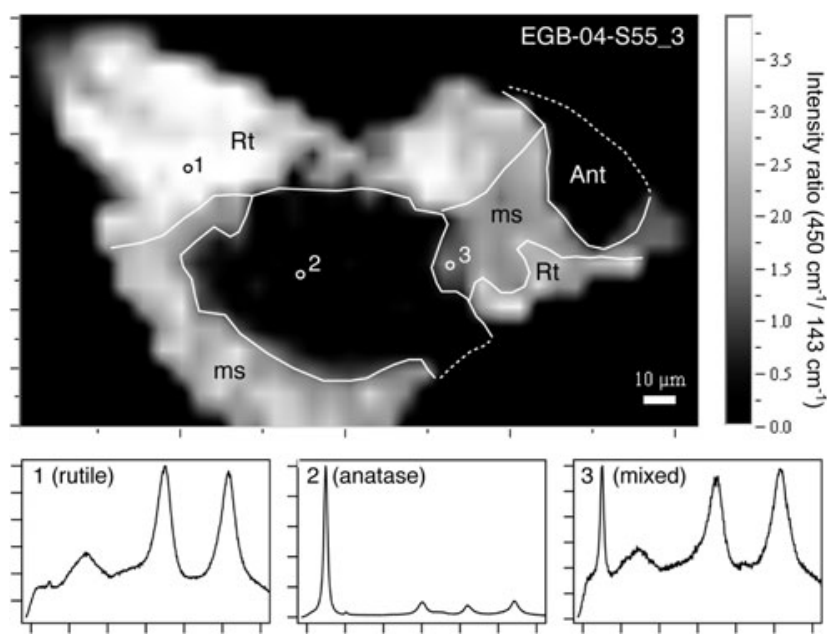

Fig. 4 Phase distribution in an ARI grain in EGB-04-S55. Numbers in the Raman map indicate spot analysis positions of the spectra given below. Rutile $(R t)$, anatase (Ant) and mixed spectra $(m s)$ regions are approximated after comparison with the backscattered-electron (BSE) image shown in Fig. 8 in order to take cracks into account, which would give darker colors. The regions show display areas of approximately homogeneous phase composition

of ca. $1 \mu \mathrm{m}$ are obtained. Therefore, mixed spectra regions may derive from a locally shallow phase-boundary between anatase and rutile. But just as likely is a derivation from a sub- $\mu \mathrm{m}$ phase mixture.

In sample HUY-1, 34 anatase- and 31 rutile crystals were analyzed. In sample WAR-9, 26 anatase- and 34 rutile crystals were analyzed. Both samples contain rutile and anatase in almost equal fractions and no brookite. In the Erzgebirge samples, $\mathrm{TiO}_{2}$ polymorph contents are more diverse. A list of Raman spot analyses is given in Table 3. Rutile crystals with anatase rims (only two cases observed) are entirely grouped as rutile in this list, even though the anatase rim was analyzed, and in trace element statistics, they occur as isolated phases. ARI grains are grouped by their spot analysis result. Due to their textures (as described previously), ARI grains are more likely to occur as anatase or rutile in trace element (TE) statistics than as mixed spectrum.

Comparing spot analysis results between different Erzgebirge units (Table 3), the largest fractions of anatase occur in sediments derived from the medium $\mathrm{T}$ units GPU, MU, and EMU. Fractions of anatase and mixed spectrum are not directly related. Mixed-spectrum occurrence is lowest in the lowermost metamorphic units OS and PU, whereas anatase occurrence is lowest in the uppermost metamorphic eclogite-rich units EGU1 and EGU2. In EMU, the largest fraction of anatase was found in the quartzite EGB-04-S56. Brookite fractions are low and uniformly distributed.
Optical and scanning-electron-optical microscopy

To identify $\mathrm{TiO}_{2}$ single crystals in embedded preparates, optical criteria like birefringence, which differs for anatase dependent on orientation, interference patterns and crystal shape can only be used in particular cases. Light refraction is high and only slightly different for each polymorph and hence cannot be decisive in single crystal preparates. Crystal color, in contrast, in most cases is practically suitable for identification. Additionally, degree of rounding, twinning, and backscattered-electron (BSE) intensity contrasts can give indications.

In the Erzgebirge samples, anatase is colorless to lightly yellowish in plain-polarized transmitted light. In backscattered-electron images in compositional (COMPO) mode, we find more or less pronounced zonation in most cases (Fig. 5a). No rounded anatase crystals were observed. Growth textures (Fig. 6a, b) indicate static growth of anatase late in the metamorphic cycle, after deformation took place.

Rutile mostly shows yellowish, brownish, or reddish colors (Fig. 5 b). Often, rutiles are rounded (Fig. 5b) and/or exhibit twinning striae in or in a right angle to elongation direction (Fig. 5b, e). Although rutile crystals are mostly homogeneous in BSE images, zonation occurs quite often (Fig. 5d). When trace element contents are high (certain elements, e.g., Fe, Sn and W, can reach contents larger than $10,000 \mathrm{ppm})$, strongly zoned rutile can be observed.

The seven brookite crystals we found in the Erzgebirge samples are lightly yellowish in transmitted light and homogeneous in BSE images. No rounding was observed. ARI grains exhibit the same optical characteristics as rutiles. In rare cases where anatase rims or contacts rutile, a contrast in BSE intensity can be observed (Fig. 7). Anatase can be lighter or darker than rutile. When anatase occurs in ARI grains, no systematic BSE contrast can be observed (Fig. 8 shows the same crystal as was used for the Raman map in Fig. 4).

To summarize, in the Erzgebirge samples, rutile, anatase, ARI, and brookite cannot be distinguished in all cases by means of optical microscopy. Doubts in identification arise due to the variability of rutile characteristics (Fig. 5) and due to the similarity of anatase/brookite and rutile/ ARI. Anatase single crystals and anatase rims on rutile can be identified as such, whereas zones of anatase in ARI grains are optically indistinguishable from the surrounding rutile. For HUY and WAR samples, separation can be done by optical means (compare Fig. 9). In both samples, rutiles are strongly colored and rounded, whereas anatase occurs as colorless, idiomorphic single crystals or crystal aggregates with clear diagenetic origin. In WAR-9, few anatase crystals appear subangular (Fig. 9e), possibly pointing to a relocation (sedimentary recycling) after growth of anatase. 
Table 3 Raman $\mathrm{TiO}_{2}$ phase results of Erzgebirge samples and units
Maximum $T=$ Maximum temperature estimates, see also Fig. 2. As no unit metamorphic temperature estimates exist for the OS, we assume that its maximum temperature is lower than the higher-metamorphic $\mathrm{PU}$ temperatures, which is then $<400^{\circ} \mathrm{C}$. The PU maximum temperature may have been nearly $400^{\circ} \mathrm{C}$. Rt Rutile, $m s$ mixed spectrum, Ant anatase, Brk brookite. Sample EGB-04S56 is a quartzite, the only rock sample described in this contribution

\begin{tabular}{|c|c|c|c|c|c|c|c|}
\hline \multirow[t]{2}{*}{ Sample } & \multirow{2}{*}{$\begin{array}{l}\text { Metamorphic } \\
\text { unit }\end{array}$} & \multirow{2}{*}{$\begin{array}{l}\text { Maximum } \\
T\left({ }^{\circ} \mathrm{C}\right)\end{array}$} & \multirow{2}{*}{$\begin{array}{l}\text { Crystals } \\
\text { in total }\end{array}$} & \multicolumn{4}{|c|}{ Fractions of } \\
\hline & & & & Rt & $\mathrm{ms}$ & Ant & Brk \\
\hline EGB-05-S69 & OS & $<400$ & 37 & 0.92 & 0.00 & 0.08 & 0.00 \\
\hline EGB-05-S70 & OS & $<400$ & 37 & 0.81 & 0.05 & 0.08 & 0.05 \\
\hline EGB-05-S51 & PU & 400 & 34 & 0.97 & 0.00 & 0.03 & 0.00 \\
\hline EGB-05-S67 & PU & 400 & 20 & 0.80 & 0.00 & 0.15 & 0.05 \\
\hline EGB-04-S61 & PU & 400 & 10 & 0.70 & 0.00 & 0.30 & 0.00 \\
\hline EGB-04-S63 & GPU & 480 & 41 & 0.59 & 0.10 & 0.32 & 0.00 \\
\hline EGB-05-S64 & GPU & 480 & 32 & 0.47 & 0.03 & 0.50 & 0.00 \\
\hline EGB-04-S62 & MU & 550 & 17 & 0.82 & 0.00 & 0.18 & 0.00 \\
\hline EGB-05-S50 & MU & 550 & 30 & 0.73 & 0.20 & 0.07 & 0.00 \\
\hline EGB-05-S52 & MU & 550 & 32 & 0.69 & 0.19 & 0.13 & 0.00 \\
\hline EGB-05-S53 & MU & 550 & 40 & 0.48 & 0.20 & 0.28 & 0.05 \\
\hline EGB-05-S65 & MU & 550 & 29 & 0.79 & 0.14 & 0.07 & 0.00 \\
\hline EGB-04-S55 & MU & 550 & 41 & 0.68 & 0.10 & 0.17 & 0.00 \\
\hline EGB-04-S51 & EMU & 650 & 45 & 0.87 & 0.09 & 0.04 & 0.00 \\
\hline EGB-04-S53 & EMU & 650 & 34 & 0.65 & 0.12 & 0.21 & 0.03 \\
\hline EGB-04-S56 & EMU & 650 & 15 & 0.53 & 0.00 & 0.47 & 0.00 \\
\hline EGB-05-S56 & EGU2 & 750 & 30 & 0.80 & 0.20 & 0.00 & 0.00 \\
\hline EGB-05-S57 & EGU2 & 750 & 31 & 0.94 & 0.06 & 0.00 & 0.00 \\
\hline EGB-04-S57 & $\mathrm{GU}$ & 800 & 31 & 0.87 & 0.10 & 0.03 & 0.00 \\
\hline EGB-05-S54 & $\mathrm{GU}$ & 800 & 17 & 0.65 & 0.00 & 0.35 & 0.00 \\
\hline EGB-05-S55 & GU & 800 & 29 & 0.86 & 0.10 & 0.03 & 0.00 \\
\hline EGB-05-S61 & $\mathrm{GU}$ & 800 & 29 & 0.93 & 0.00 & 0.03 & 0.03 \\
\hline EGB-05-S63 & GU & 800 & 28 & 0.75 & 0.07 & 0.18 & 0.00 \\
\hline EGB-04-S41 & EGU1 & 950 & 30 & 0.90 & 0.10 & 0.00 & 0.00 \\
\hline EGB-04-S50 & EGU1 & 950 & 45 & 0.96 & 0.04 & 0.00 & 0.00 \\
\hline EGB-04-S50 & EGU1 & 950 & 49 & 0.98 & 0.02 & 0.00 & 0.00 \\
\hline EGB-05-S49 & EGU1 & 950 & 32 & 0.91 & 0.09 & 0.00 & 0.00 \\
\hline EGB-04-S45 & EGU1 & 950 & 30 & 1.00 & 0.00 & 0.00 & 0.00 \\
\hline EGB-05-S68 & Kirchberg granite & & 4 & 0.00 & 0.00 & 1.00 & 0.00 \\
\hline Unit total & OS & $<400$ & 74 & 0.86 & 0.03 & 0.08 & 0.03 \\
\hline Unit total & $\mathrm{PU}$ & 400 & 64 & 0.88 & 0.00 & 0.11 & 0.02 \\
\hline Unit total & GPU & 480 & 73 & 0.53 & 0.07 & 0.40 & 0.00 \\
\hline Unit total & MU & 550 & 187 & 0.68 & 0.15 & 0.16 & 0.01 \\
\hline Unit total & EMU & 650 & 94 & 0.73 & 0.09 & 0.17 & 0.01 \\
\hline Unit total & EGU2 & 750 & 61 & 0.87 & 0.13 & 0.00 & 0.00 \\
\hline Unit total & GU & 800 & 134 & 0.83 & 0.06 & 0.10 & 0.01 \\
\hline Unit total & EGU1 & 950 & 186 & 0.95 & 0.05 & 0.00 & 0.00 \\
\hline
\end{tabular}

From frequent observations the surmise arose, that anatase displays cathodoluminescence (CL) under the electron beam in Erzgebirge rock samples, while rutile does not. However, we cannot confirm these findings, as both anatase and rutile show CL, with varying intensities. Further, CL intensity diminishes during electron bombardment and thus constitutes no reliable property for discrimination.
Trace elements

\section{Polymorph discrimination}

Using the Raman phase analysis data in combination with TE contents, it is possible to classify polymorphs into groups with different TE contents. For the samples with well-defined phase information (HUY-1, WAR-9, and the 


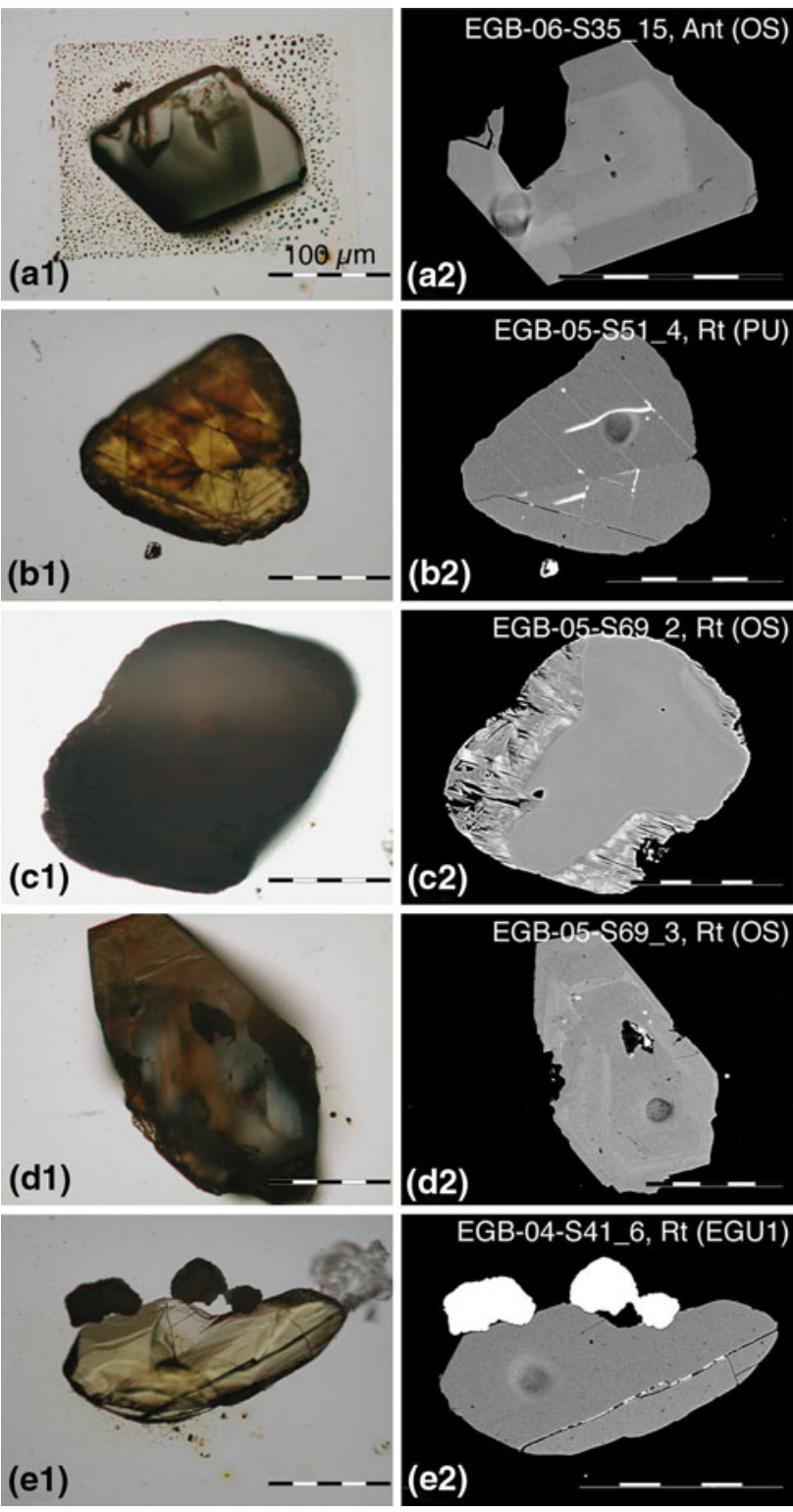

Fig. 5 Optical and scanning-electron images of anatase- and rutile crystals from different Erzgebirge samples. (1) Plain-polarized transmitted light, (2) backscatter-electrons in COMPO mode. Ant Anatase, $R t$ rutile. The rim on rutile crystal $\mathbf{c}$ is rutile as well. Circular depressions in $\mathbf{b}, \mathbf{d}$, and $\mathbf{e}$ are secondary-ion-microprobe analysis pits

single crystals, compare Table OR2 in the Online Resource), this is particularly obvious (Fig. 10). In scatterplots, $\mathrm{V}$ and $\mathrm{Cr}$ are best suited for classification ${ }^{1}$ : Anatase has low contents of both $\mathrm{Cr}$ and $\mathrm{V}$ (below about $200 \mathrm{ppm}$ ) compared to rutile. Even though brookite crystals cannot be

\footnotetext{
${ }^{1}$ Due to interference with $\mathrm{Ti} \mathrm{K} \beta$, the detection limit for $\mathrm{V}$ is very high (220 ppm, compare Table 2). Consequently, the bigger part of anatase analyses plot below the $\mathrm{V}$ detection limit. Yet, as errors are comparatively small $(70 \mathrm{ppm})$, anatase $\mathrm{V}$ values (comparable in accuracy with $\mathrm{Cr}$ values) still have significance when plotting near the detection limit.
}

classified as an own group in scatter-plots, there is a tendency toward low $\mathrm{Cr} / \mathrm{V}$ ratios.

In sample HUY-1, we found one double crystal with rounded rutile and idiomorphic anatase in direct contact (Fig. 9a). Analyzing both of them, we find that these two crystals fit well into the respective probability regions (Fig. 11).

Similarly, anatase found in contact with rutile in the Erzgebirge samples (Fig. 7) shows distinct TE characteristics with low $\mathrm{Cr}$ - and $\mathrm{V}$ contents (Table 4). For EMP analysis results of Erzgebirge samples, see Table OR1 in the Online Resource. Anatase in ARI grains, however, generally exhibits similar $\mathrm{Cr}$ - and $\mathrm{V}$ contents as the adjacent rutile (Table 4). In addition to $\mathrm{Cr}$ and $\mathrm{V}$, as shown in Table $4, \mathrm{Nb}, \mathrm{Al}$, and $\mathrm{Zr}$ contents are different between anatase and rutile for the two grains where both phases are in contact. This observation is indicative for few of the mentioned elements but is not representative for the whole data set [which is emphasized by the linear discriminant analysis (LDA) results shown in Table 5]. Elevated W contents for the anatase analysis in the ARI grain must not be overvalued as this analysis was done inside an area with high electron-backscattering (see Fig. 8) and thus is not representative for the whole anatase region inside that grain.

The relatively high amount of anatase and brookite in Erzgebirge samples appears to be exceptional. We also collected samples from the Alps, Syros, and Mexico, but no anatase and brookite were found. Results from the latter samples are shown in Table OR3 in the Online Resource. Figure 12 shows that TE contents of these rutiles fit well with the characteristics observed for other samples discussed previously. The large scattering in $\mathrm{Cr}$ contents points to a comparably higher significance of $\mathrm{V}$ values for classification purposes.

In order to find a better separation of groups, we applied an LDA to the log-transformed proportions of the analyzed elements, ${ }^{2}$ again using only those samples with welldefined phase information (HUY-1, WAR-9 and the single crystals) in order to discriminate rutile, anatase, and brookite. The result is shown in Table 5.

A cross-classification of the same data set (Table 6) shows that by means of this $\mathrm{LDA}$, all $\mathrm{TiO}_{2}$ polymorphs (brookite as well) can be separated from each other, with percentages of correctly classified crystals ranging from 97\% (rutile) via $84 \%$ (anatase) to $71 \%$ (brookite).

\footnotetext{
2 This approach precludes analyses with "0" concentrations for any element, or requires zero replacement strategies (compare van den Boogart et al. 2006). In order to have a significant and representative dataset, analyses below detection limit were not changed to " 0 " or any other number. For the same reason, $\mathrm{W}$ and $\mathrm{Al}$ analyses were not included, as these obtained " 0 " for too many crystals.
} 
Fig. 6 Scanning-electron images of anatase in a Bt-CldGrt-Phe schist from MU in the Erzgebirge (sample 61-c2)
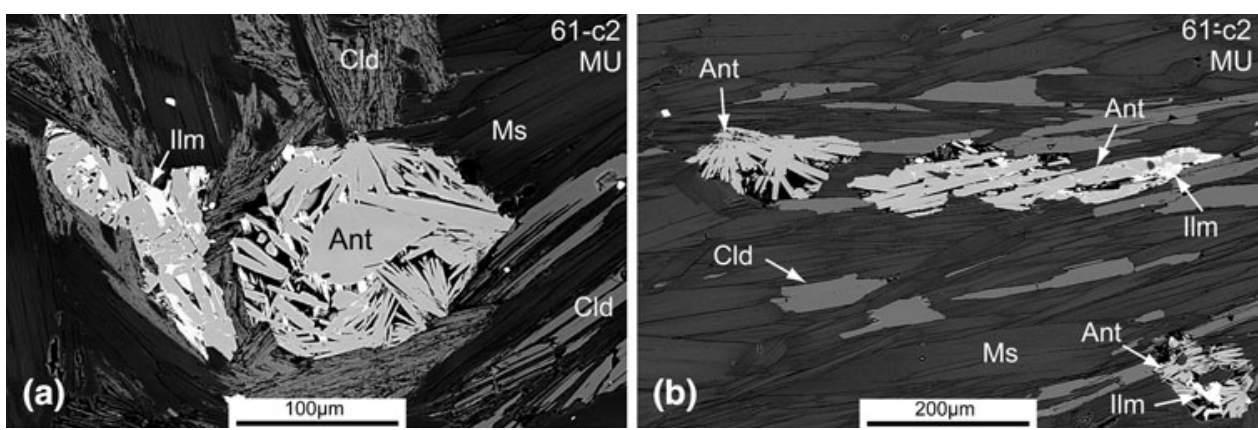

Fig. 7 Scanning-electron (BSE in COMPO mode) images of two crystals with anatase rim and contact. Circles show EMP analysis locations, compare Table 4. a $1=$ anatase, 2 and $3=$ rutile. $\mathbf{b} 1=$ anatase, $2=$ rutile
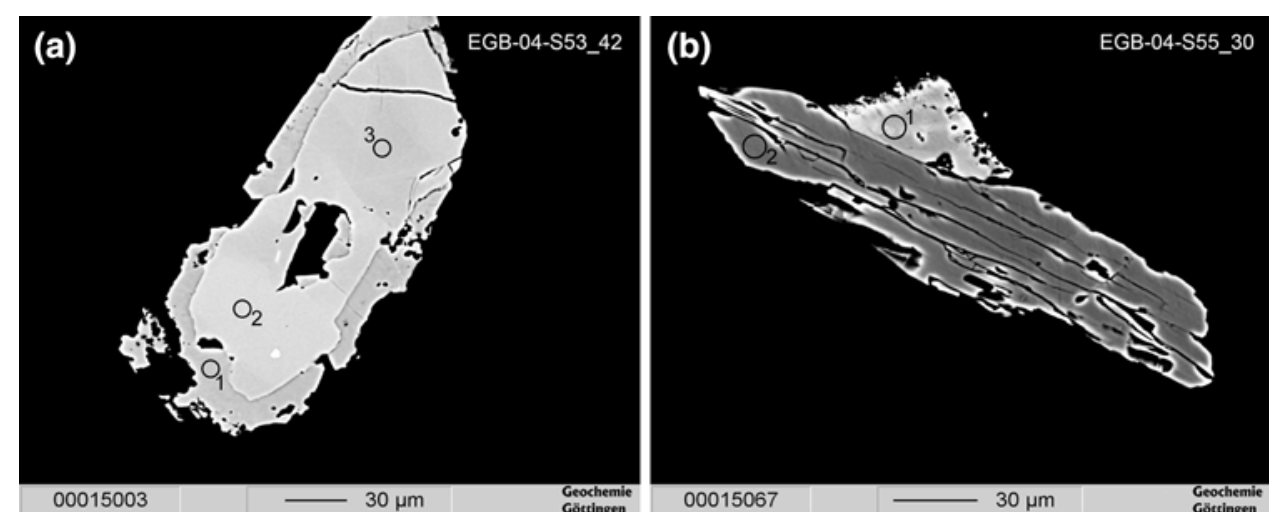
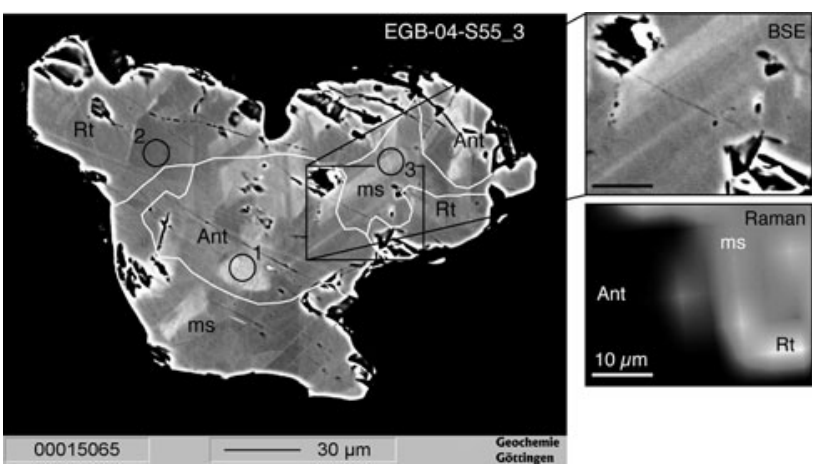

Fig. 8 Scanning-electron (BSE in COMPO mode) image of an ARI grain in EGB-04-S55 (same grain as shown in Fig. 4). Rt Rutile, Ant anatase, $m s$ mixed spectrum. Areas of similar phase composition are separated by white lines according to Fig. 4. Circles show EMP analysis locations, compare Table 4 . The closeup (equal area as BSE and Raman signal) points out that the phase transition is not accompanied by a BSE intensity change

By reclassifying Erzgebirge analyses (Table 7) by means of LDA results from HUY-1, WAR-9, and the single crystals (which was shown in Table 5), we find that analyses formerly classified as rutile by Raman single spot analysis are almost all ( $>99 \%)$ reclassified as rutile by LDA, whereas analyses formerly classified as anatase are reclassified as rutile in 49 of 92 cases (ca. 53\%). This result for anatase in the majority of cases must derive from ARI grains classified as anatase in Raman spot analysis.
Similarly, we can show that mixed-spectrum analyses in the majority (74 out of 76 analyses) are classified as rutile. Brookite analyses are completely reclassified as rutile.

The LDA results indicate that we find mainly one linear discriminant (LD1) suitable for separation. Besides $\mathrm{Cr}$ and $\mathrm{V}, \mathrm{Fe}$ and $\mathrm{Nb}$ play an important role for discrimination, a fact that is obscured in simple scatter-plots.

\section{Thermometry}

In order to further investigate the influence of polymorph type on $\mathrm{Zr}$ contents (maximum values are used for thermometry), we take a closer look on samples where a direct comparison is possible: HUY-1 (Fig. 13a), WAR-9 (Fig. 13b), and the Erzgebirge samples sorted by their unit affiliation (Fig. 14). Even considering only those anatase analyses, which would be grouped as anatase by their TE contents (low V concentrations), in many cases (HUY-1, WAR-9, and the Erzgebirge units MU, EMU, and GU), anatase maximum $\mathrm{Zr}$ contents correspond very well to rutile maximum $\mathrm{Zr}$ contents, which range from ca. 300 ppm (2.5 log-units; MU) via 1,000 ppm (3 log-units; EMU and GU) to 3,000 ppm (3.5 log-units; HUY-1 and WAR-9). The finding that $\mathrm{Zr}$ contents in anatase are systematically related to $\mathrm{Zr}$ contents in rutiles which are locally and geochemically associated is strengthened by Erzgebirge quartzite EGB-04-S56, which provides the main part and the highest $\mathrm{Zr}$ contents of rutile and anatase 
Fig. 9 Optical (transmitted light) and scanning-electron images of anatase- and rutile crystals in a-c HUY and d-f WAR samples. a Rutile and idiomorphic anatase, $\mathbf{b}$ anatase, c anatase, $\mathbf{d}$ rutile, $\mathbf{e}$ anatase, f anatase
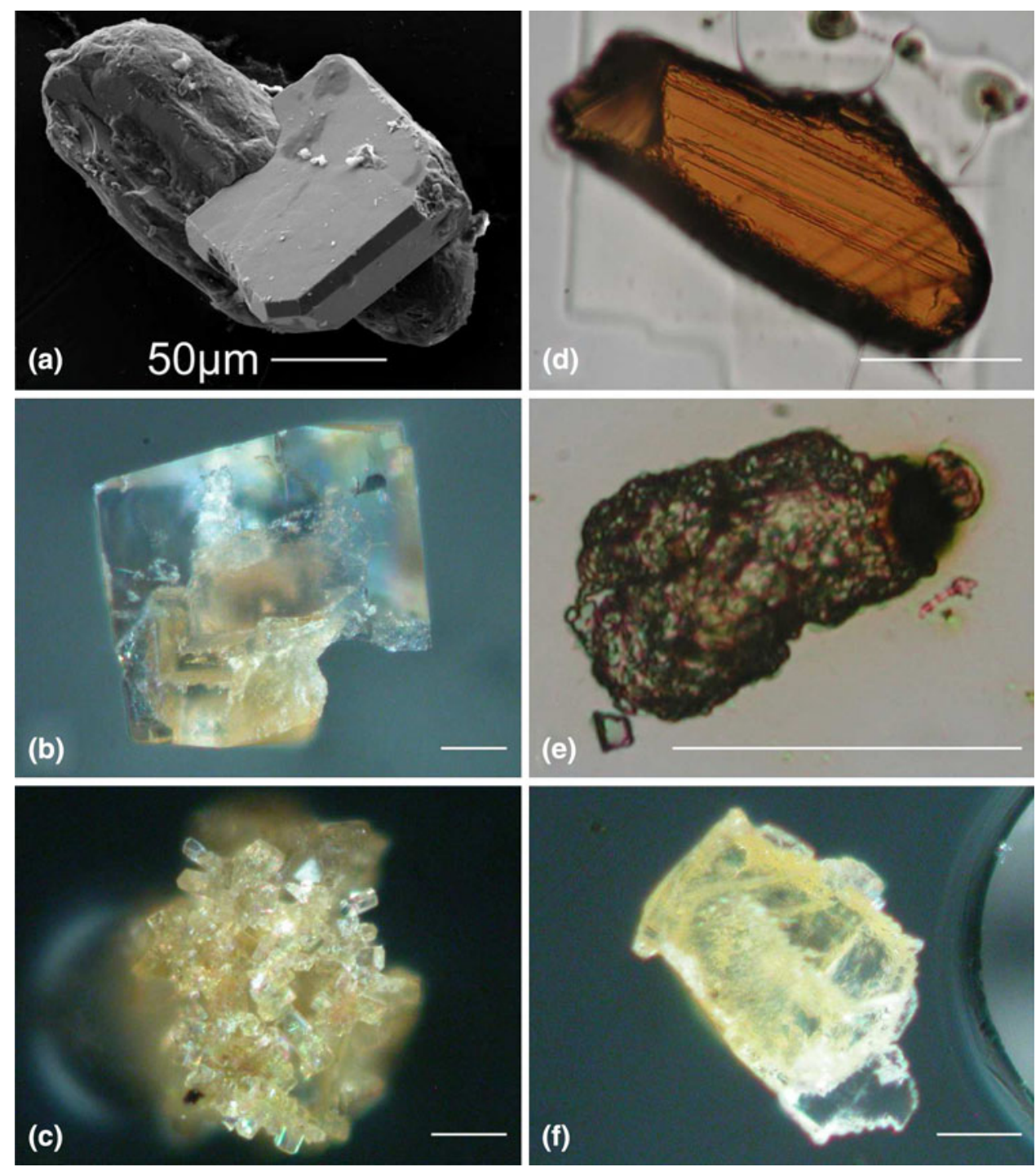

analyses showing temperatures exceeding unit metamorphic temperature in EMU.

In samples deriving from the low-temperature units of the Erzgebirge (PU and GPU), anatase maximum $\mathrm{Zr}$ contents are considerably lower than rutile maximum contents, only few analyses exceed the detection limit ( $40 \mathrm{ppm}$ or 1.6 log-units).

Despite the obvious relation between maximum $\mathrm{Zr}$ contents in anatase and rutile analyses from the same samples or units, $\mathrm{Zr}$ contents in anatase exhibit larger variances and also tend to lower mean values compared to rutiles.

A comparison of Fig. 14 with Table 3 shows that fractions of ARI grains in the metamorphic units derived from mixed-spectrum analysis fractions are low in the lowermost units, whereas TE contents indicate that in the lowermost metamorphic units ARI grains are rather represented by anatase. Hence, in the lowermost metamorphic Erzgebirge units, ARI grain fractions are similar to those in the uppermost metamorphic units.

\section{Discussion}

Occurrence and TE characteristics of anatase

In the studied samples (Fig. 12), anatase does not occur in each metamorphic or sedimentary environment, where rutile is present. Anatase in samples HUY-1 and WAR-9 evidently originates from a diagenetic setting (Fig. 9), whereas anatase in Erzgebirge samples may have formed at metamorphic conditions as well. The similarity between anatase and rutile $\mathrm{Zr}$ contents points to a local connection between both phases and hence a derivation from the same source rocks in the majority of cases. Direct evidence for anatase occurrence in metamorphic rocks comes from 


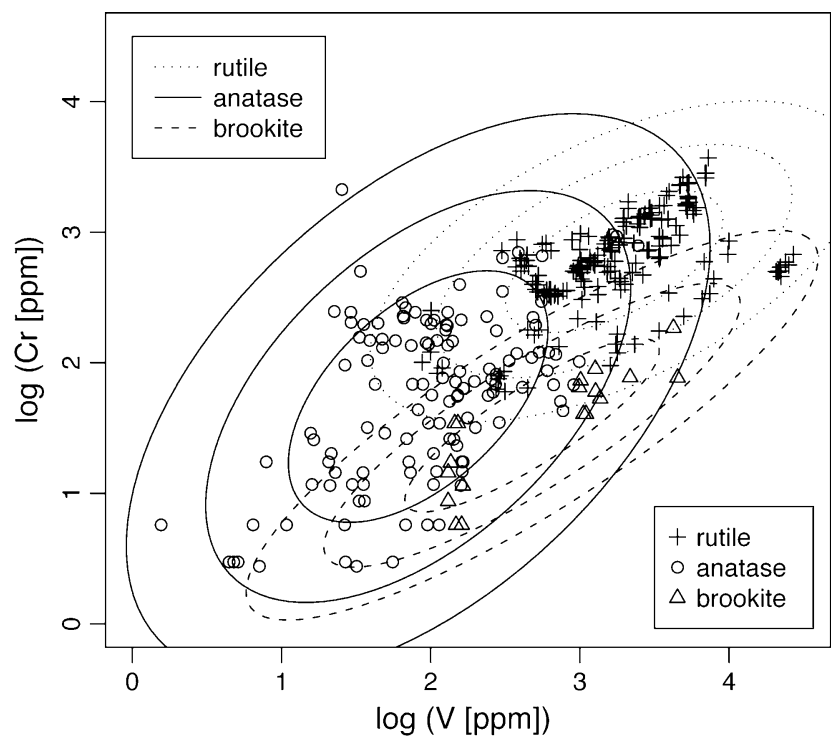

Fig. $10 \mathrm{~V}$ vs. Cr plot for samples HUY and WAR, and the single crystals. Ellipses indicate 1-, 2-, and $3-\sigma$ probability regions. Detection limits are at 220 and $50 \mathrm{ppm}$ for $\mathrm{V}$ and $\mathrm{Cr}$, respectively

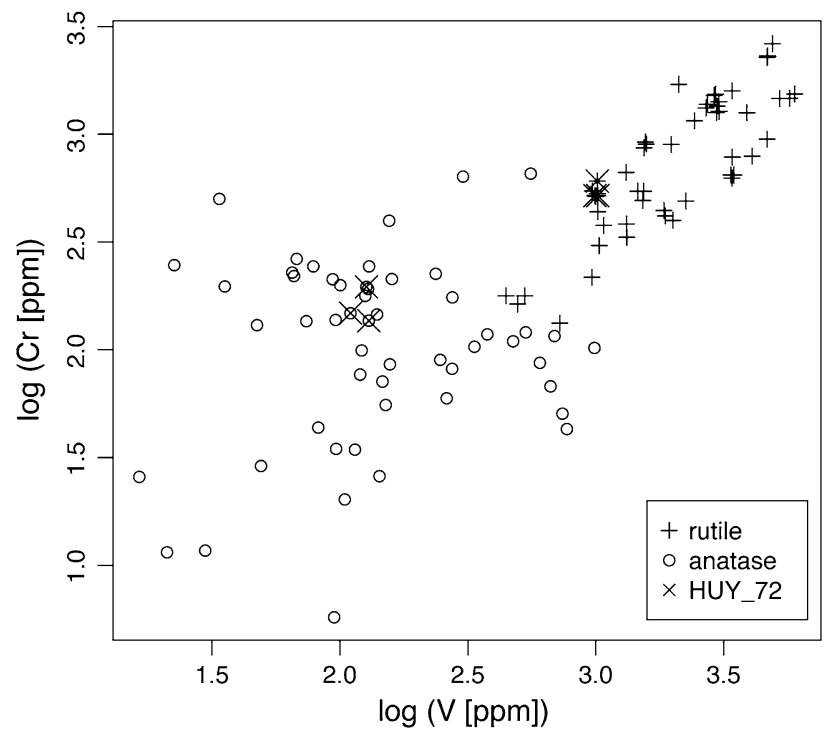

Fig. $11 \mathrm{~V}$ vs. $\mathrm{Cr}$ plot for $\mathrm{TiO}_{2}$ grains from sample HUY-1, pointing out the analyses of the anatase-rutile double crystal shown in Fig. 9a (grain no. 72 in sample HUY)

anatase in a quartzite sample in Erzgebirge (EGB-04-S56), which provides the main part of anatase found in samples from EMU.

The idiomorphic or nearly idiomorphic habit of anatase in Erzgebirge samples (Fig. 5) and static growth textures (Fig. 6) indicate that it cannot be an inherited phase, but that it has grown rather late in the metamorphic cycle of its host rocks (after peak-metamorphism and deformation). The absence of anatase and occurrence of ARI grains in the lowest-metamorphic unit OS (compare Fig. 14) possibly points to metamorphic reactions too slow for a complete transformation to anatase.

The absence of anatase in the high-grade, high-pressure units (EGU1 and EGU2; compare Table 3; Fig. 14) may have its origin in reaction kinetics. Very rapid exhumation may result in a lack of time for the growth of anatase. On the other hand, the fact that the main fraction of anatase in EMU is delivered by a quartzite, together with the lack of anatase in the other eclogite-rich units (EGU1 and EGU2) points to a disability of eclogites to produce anatase.

We have demonstrated that anatase is different from rutile in the concentrations of all analyzed trace elements (Table 4), but only for certain elements (namely V, Cr, Fe, and $\mathrm{Nb}$; compare Table 5), these differences are systematic and hence suitable for polymorph classification.

In those Erzgebirge units where anatase does not occur, ARIs are still present. In the elements, which are diagnostic for an assignment to $\mathrm{TiO}_{2}$ polymorphs after LDA, no difference can be found between ARI and rutile (see Table 7). From the observation of Raman mappings (Fig. 4) we may argue that ARIs represent the beginning of recrystallization of rutile to anatase and therefore constitute a (still unequilibrated) transitional stage between rutile and anatase. As zoning patterns in ARIs (Fig. 8) exhibit no contrast between rutile, anatase, and mixed-spectrum regions, we conclude that at least during in situ recrystallization, anatase maintains the major part of former rutile's trace element budget. A similar feature was observed by Yang and Rivers (2001), who find that $\mathrm{Cr}$ zoning in garnet indicates that the garnet overprinted a fabric defined by $\mathrm{Cr}$-rich (mica, chlorite, epidote) and Cr-poor (quartz, plagioclase) layers during growth (overprint zoning). Supposedly, an equilibration of anatase TE contents and hence a separation of rutile and anatase TE groupings takes place when recrystallization involves nucleation in another place or/ and when completely recrystallized grains are given the possibility (e.g., given time and existence of a fluid) to equilibrate. Possibly, $\mathrm{Zr}$ is among the last elements to readjust in the equilibration process of anatase, as indicated by the systematic relation between $\mathrm{Zr}$ contents in rutile and anatase, where $\mathrm{V}, \mathrm{Cr}, \mathrm{Fe}$, and $\mathrm{Nb}$ can already be assigned to rutile- and anatase groupings. However, the larger variance in $\mathrm{Zr}$ contents and the tendency toward sub-detection limit $\mathrm{Zr}$ concentrations of anatase points to an evolution toward low $\mathrm{Zr}$ concentrations in equilibrium state.

Anatase in thermometry

The accordance between anatase and rutile $\mathrm{Zr}$ contents is well for many samples, but not good enough to use anatase as $\mathrm{Zr}$-in-rutile thermometer. Not only are $\mathrm{Zr}$ concentration variances different between anatase and rutile, but also in 
Table 4 Table showing analysis results for the crystals and analysis spots shown in Figs. 7 and 8

\begin{tabular}{lcccccrrrr}
\hline Label & $\mathrm{Nb}(\mathrm{ppm})$ & $\mathrm{Cr}(\mathrm{ppm})$ & $\mathrm{W}(\mathrm{ppm})$ & $\mathrm{Sn}(\mathrm{ppm})$ & $\mathrm{Al}(\mathrm{ppm})$ & $\mathrm{Fe}(\mathrm{ppm})$ & $\mathrm{V}(\mathrm{ppm})$ & $\mathrm{Zr}(\mathrm{ppm})$ & $\mathrm{Si}(\mathrm{ppm})$ \\
\hline Rutile and anatase in contact & & & & & & & \\
EGB-04-S53_42_1 & 792 & 110 & 0 & 16 & 247 & 285 & 20 & 0 \\
EGB-04-S53_42_2 & 1,792 & 580 & 132 & 80 & 0 & 2,189 & 912 & 72 \\
EGB-04-S53_42_3 & 1,801 & 554 & 57 & 109 & 0 & 2,258 & 952 & 65 & 0 \\
EGB-04-S55_30_1 & 498 & 53 & 5,562 & 25 & 714 & 3,710 & 109 & 12 & 603 \\
EGB-04-S55_30_2 & 2,991 & 150 & 79 & 45 & 40 & 2,644 & 1,433 & 35 \\
ARI & & & & & & & 14 \\
EGB-04-S55_3_1 & 835 & 1,822 & 10,071 & 284 & 47 & 4,290 & 1,763 & 104 \\
EGB-04-S55_3_2 & 1,125 & 1,235 & 2,262 & 164 & 11 & 2,278 & 1,217 & 141 \\
EGB-04-S55_3_3 & 1,011 & 2,121 & 6,843 & 264 & 107 & 3,225 & 1,553 & 128
\end{tabular}

Analyses EGB...1 correspond to analysis spots (1) in Figs. 7 and 8 and are identified as anatase by Raman spectroscopy, analyses EGB...2 and EGB...3, correspondingly, are identified as rutile

Table 5 Table showing details and result of the linear discriminant analysis for samples HUY-1, WAR-9, and the single crystals

\begin{tabular}{|c|c|c|c|c|c|c|}
\hline Anatase & Brookite & & & & & \\
\hline \multicolumn{7}{|c|}{ Prior probabilities of groups } \\
\hline 0.32764505 & 0.04778157 & \multicolumn{2}{|c|}{0.62457338} & & & \\
\hline $\log$ (element) & $\mathrm{Nb}(\mathrm{ppm})$ & $\mathrm{Cr}(\mathrm{ppm})$ & Sn (ppm) & $\mathrm{Fe}(\mathrm{ppm})$ & $\mathrm{V}(\mathrm{ppm})$ & $\mathrm{Zr}(\mathrm{ppm})$ \\
\hline \multicolumn{7}{|l|}{ Group means } \\
\hline Anatase & 3.195607 & 1.823492 & 1.516392 & 3.239008 & 2.043290 & 2.22702 \\
\hline Brookite & 3.731985 & 1.530200 & 1.176514 & 3.497468 & 2.710993 & 1.353895 \\
\hline \multirow[t]{2}{*}{ Rutile } & 3.258939 & 2.781853 & 1.935055 & 3.327488 & 3.217666 & 2.437146 \\
\hline & LD1 & \multicolumn{2}{|c|}{ LD2 } & & & \\
\hline \multicolumn{7}{|c|}{ Coefficients of linear discriminants } \\
\hline $\mathrm{Nb}(\mathrm{ppm})$ & -0.6926381 & \multicolumn{2}{|c|}{-0.4400006} & & & \\
\hline $\mathrm{Cr}(\mathrm{ppm})$ & 1.0632667 & \multicolumn{2}{|c|}{1.1558577} & & & \\
\hline Sn (ppm) & 0.3895570 & \multicolumn{2}{|c|}{0.9713190} & & & \\
\hline $\mathrm{Fe}(\mathrm{ppm})$ & 0.7630163 & \multicolumn{2}{|c|}{-0.1888737} & & & \\
\hline $\mathrm{V}(\mathrm{ppm})$ & 1.3390162 & \multicolumn{2}{|c|}{-1.6312138} & & & \\
\hline $\mathrm{Zr}(\mathrm{ppm})$ & -0.1898791 & \multicolumn{2}{|c|}{0.8305665} & & & \\
\hline LD1 & LD2 & & & & & \\
\hline \multicolumn{7}{|c|}{ Proportion of trace } \\
\hline 0.8407 & 0.1593 & & & & & \\
\hline
\end{tabular}

two Erzgebirge units (PU and GPU), maximum Zr contents in anatase are different from rutile.

For similar reasons, Zr-in-anatase thermometry will not work: Although $\mathrm{Zr}$ incorporation into anatase must follow similar rules as $\mathrm{Zr}$ incorporation into rutile, the observed accordance between both phases' $\mathrm{Zr}$ contents is too well and covers a too large concentration range (2.5-3.5 logunits) to be coincidental. Hence, we conclude that $\mathrm{Zr}$ contents in anatase cannot be used for direct thermometry, as they do not mirror anatase growth conditions, but obviously those of coexisting rutiles.

The petrological process behind the equilibration of $\mathrm{Zr}$ contents in anatase (compare last paragraph in Sect. "Occurrence and TE characteristics of anatase") needs further investigation. On the one hand, $\mathrm{Zr}$ contents in anatase are comparable to rutile $\mathrm{Zr}$ contents, even when these are not equilibrated at metamorphic conditions at the time of anatase growth themselves. This is best shown for 


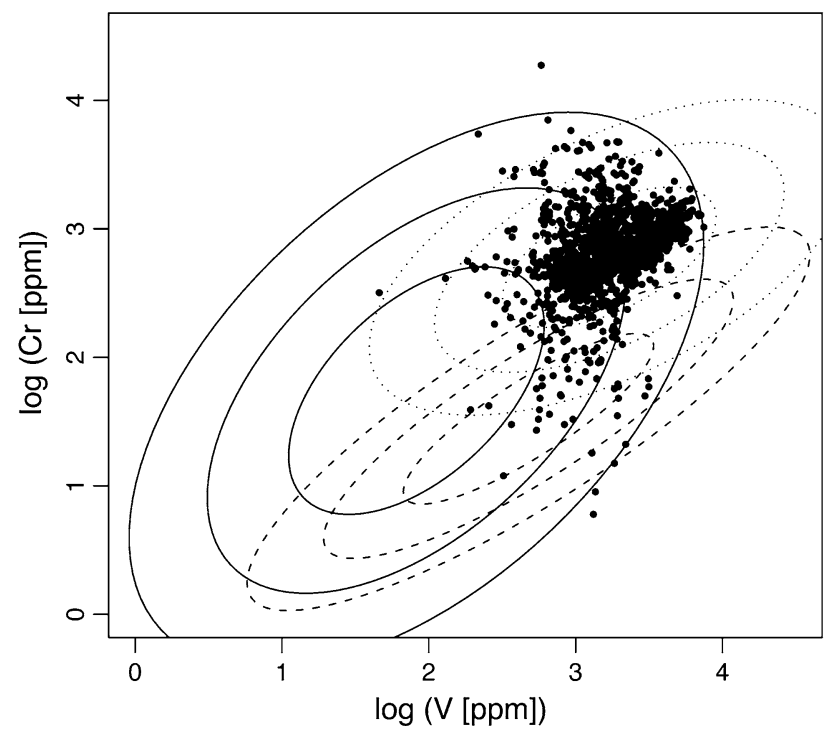

Fig. $12 \mathrm{Cr}$ vs. V for samples from the Alps, Syros and Mexico (see Table OR3 in the Online Resource) with 1-, 2-, and 3- $\sigma$ probability regions for rutile, anatase, and brookite (compare Fig. 10)

diagenetic anatase in HUY-1 and WAR-9, whose Zr contents mirror rutiles indicating granulitic temperatures. Similarly, $\mathrm{Zr}$ contents in anatase from the upper-metamorphic Erzgebirge units MU, EMU, and GU obviously corresponds to rutile maximum $\mathrm{Zr}$ contents, even though anatase most likely grew during late retrograde metamorphism while rutiles record peak metamorphic and even inherited temperatures.

On the other hand, maximum $\mathrm{Zr}$ concentrations in anatase in the lower metamorphic Erzgebirge units PU and GPU are considerably lower than in associated rutiles. Due to the very low fraction of anatase in the lower metamorphic units, this finding may only be a consequence of statistics. But as OS, PU, and GPU of all units in Erzgebirge are those which retained the largest fractions of relict, high-temperature rutiles (Triebold et al. 2007), it is likely that the geochemical processes of rutile re-equilibration and in situ recrystallization of rutile to anatase (and thus anatase inheriting rutile TE characteristics) are similarly inhibited in these Erzgebirge units. The reason for this cannot merely be low temperature and pressure, as in situ crystallization and rutile re-equilibration are not linked in samples HUY-1 and WAR-9 (the first happened, the second not). Hence, we propose a reaction barrier in the low-grade Erzgebirge units, e.g. the inclusion of relict rutiles inside a host mineral or local differences in fluid activity or composition.

\section{Identification of $\mathrm{TiO}_{2}$ polymorphs}

We have applied a range of techniques to identify $\mathrm{TiO}_{2}$ polymorphs, which each has distinct advantages depending on the problem to be solved. None of these techniques leads to unambiguous results. In Raman spectroscopy, besides rutile, anatase, and brookite, we observe mixed spectra between rutile and anatase, which are, as was shown in mappings (Fig. 4), not evenly distributed in ARI grains, but represent a transition zone between pure rutile and anatase. Hence, in spot analysis, they are in the majority of cases not identified as ARI grains and may be regarded as rutile or anatase with equivalent likelihood. Therefore, using Raman spectroscopy, ARI grains can only be identified by time-consuming mappings.

By optical microscopy, anatase and brookite cannot reliably be discerned, while rutile and ARI cannot be discerned at all. Furthermore, rutiles may have the appearance of anatase and brookite in optical as well as in scanningelectron-optical microscopy.

Chemical analysis shows that anatase and rutile can be discerned by contents of $\mathrm{Cr}, \mathrm{V}, \mathrm{Fe}$, and $\mathrm{Nb}$ (Tables 6 and 7), whereas ARI grains are similar to rutile in TE contents (Table 7) and therefore cannot and need not be distinguished. Further analyses of brookites are needed to make clear whether brookite can be classified at all. In the following, we are presenting a way to classify $\mathrm{TiO}_{2}$ analyses on the basis of our LDA results.

In order to compute the classification probabilities of anatase, brookite and rutile for a given analysis, the group means and the coefficients of linear discriminants from Table 5 are applied. The prior probabilities of groups obtained from HUY, WAR, and the single crystals in Table 5 are misleading if applied to a natural data set, as these are obtained from an artificial compilation of samples. Hence, as an approximation we propose to use the prior probabilities given by the fraction totals of phases in all Erzgebirge samples, as recalculated after LDA (a comparison is shown in Table 8).

First, we compute the global mean $\mathbf{m}_{G}$, weighting the means on each group of the geochemical variables considered, $\mathbf{m}_{1}, \ldots, \mathbf{m}_{K}$, with the prior probabilities given to each phase group $\mathbf{p}^{0}=\left[p_{1}^{0}, \ldots, p_{K}^{0},\right]$ with $K=1,2,3$ (anatase, brookite and rutile),

$\mathbf{m}_{G}=\sum_{g=1}^{K} p_{i} \cdot \mathbf{m}_{i}$.

Then we use $\mathbf{m}_{G}$ to center with it both the data set (consisting of $N$ analyses $\mathbf{x}_{j}$ ) and the mean vector of each group:

$\mathbf{x}_{j}^{*}=\mathbf{x}_{j}-\mathbf{m}_{G}, \quad j=1, \ldots, N$

$\mathbf{m}_{g}^{*}=\mathbf{m}_{g}-\mathbf{m}_{G}, \quad g=1, \ldots, K$.

Taking $\mathbf{Z}$ as the matrix of coefficients of the linear discriminant functions, then the posterior probability of observation $\mathbf{x}_{j}$ to belong to group $g$ is proportional to 
Table 6 Table showing the cross-classification of all data used for linear discriminant analysis: predicted dataset means recalculated after linear discriminant analysis

\begin{tabular}{lllll} 
Predicted dataset & & Sum & $\begin{array}{l}\text { Total } \\
\text { fraction } \\
(\%)\end{array}$ & $\begin{array}{l}\text { Fraction } \\
\text { correctly } \\
\text { classified (\%) }\end{array}$ \\
\hline Anatase & Brookite & Rutile & &
\end{tabular}

Raman dataset

$\begin{array}{lllllll}\text { Anatase } & 81 & 0 & 15 & 96 & 33 & 84\end{array}$

$\begin{array}{lllllll}\text { Brookite } & 3 & 10 & 1 & 14 & 5 & 71\end{array}$

$\begin{array}{lllllll}\text { Rutile } & 5 & 1 & 177 & 183 & 62 & 97\end{array}$

Table 7 Table showing the predicted classification of Erzgebirge analyses after LDA of HUY-1, WAR-9, and the single crystals in comparison with the results of Raman spot analysis

\begin{tabular}{llllr}
\hline & \multicolumn{2}{l}{ Predicted dataset } & Sum \\
\cline { 2 - 3 } & Anatase & Brookite & Rutile & \\
\hline Raman dataset & & & & \\
Anatase & 37 & 6 & 49 & 92 \\
Brookite & 0 & 0 & 3 & 3 \\
Rutile & 2 & 2 & 785 & 789 \\
Mixed-spectrum analysis & 1 & 1 & 74 & 76 \\
Sum & 40 & 9 & 911 & 960 \\
Total fraction & $4 \%$ & $1 \%$ & $95 \%$ & \\
\hline
\end{tabular}

$p_{g}\left(\mathbf{x}_{j}\right) \propto p_{g}^{0} \cdot \exp \left[\left(\mathbf{x}_{j}^{*}\right)^{t} \cdot \mathbf{Z} \cdot \mathbf{Z}^{t} \cdot \mathbf{m}_{g}^{*}-\frac{1}{2}\left\|\mathbf{Z}^{t} \cdot \mathbf{m}_{g}^{*}\right\|^{2}\right]$.

Superscript $t$ means transposition, and $\|\mathbf{x}\|$ is the Euclidean norm of the vector $\mathbf{x}$. The proportionality constant is chosen for each sample $j$ to ensure that its $K$ probabilities sum up to one, as expected in a probability vector. A calculation

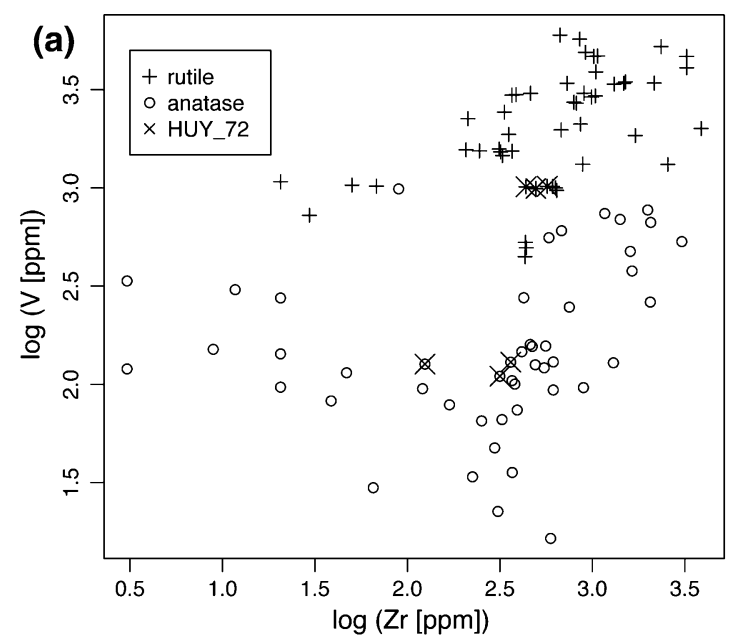

Fig. 13 Plots of $\mathrm{Zr}$ versus $\mathrm{V}$ for samples a HUY-1 and b WAR-9 sheet in Excel format is given in the Online Resource (OR4.xls).

As an example, we applied this calculation to analyses obtained in samples from the Alps, Syros and Mexico. The result is shown in Table OR3 in the Online Resource, compare also Fig. 12. In order to be able to classify all analyses, as an approximation, elements which gave " 0 " results were set to $1 \mathrm{ppm}$ (ND values). Similarly, $\mathrm{Sn}$, which was not analyzed in some samples (NA) and is not a very important element for LDA, was set to a mean value of $79 \mathrm{ppm}$. With these settings and by simply counting the (unevaluated) maximum posterior probability, we find only 1 anatase and 6 brookites together with 1,452 rutiles. As no anatase and brookite was found in Raman spot analysis, we can calculate a correct-classification rate from these data of $99.5 \%$ for the phase rutile, a result that is even more precise than given by the 2- $\sigma$ standard deviation of a normal distribution.

\section{Summary and conclusions}

We conclude that using rutile as a geological tracer requires determination of the $\mathrm{TiO}_{2}$ phase. The transitional stage ARI, frequently found in Erzgebirge samples, is similar to rutile in TE contents and hence does not need to be avoided (i.e., can be treated as rutile). Whereas $\mathrm{V}$ content, besides $\mathrm{Cr}$, represents the best single element discriminator between polymorphs, $\mathrm{Fe}$ and $\mathrm{Nb}$ also vary between anatase, brookite and rutile. Hence, a discrimination between mafic and pelitic source rocks on the basis of $\mathrm{Cr}$ and $\mathrm{Nb}$ will not work for anatase and brookite. Furthermore, $\mathrm{Zr}$ contents in anatase cannot be used for thermometry, neither as substitute for rutile in $\mathrm{Zr}$-in-rutile thermometry, nor as direct $\mathrm{Zr}$-in-anatase thermometer.

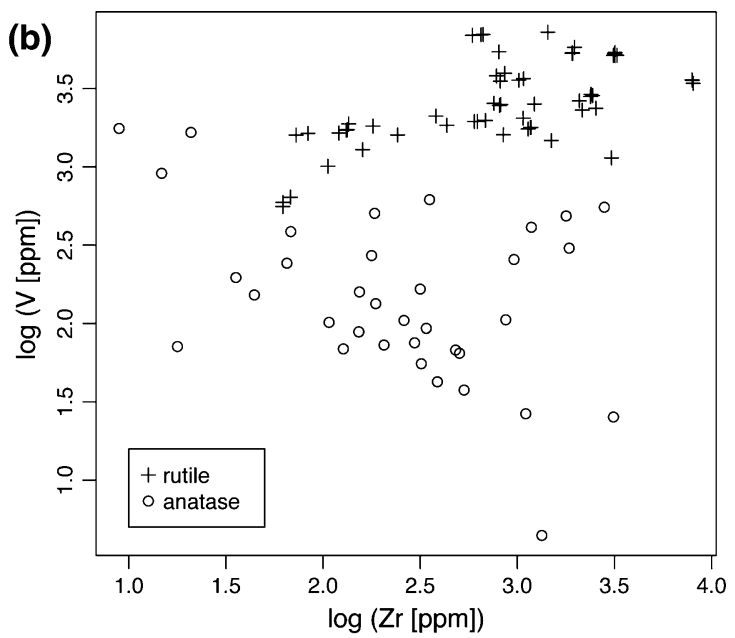


Fig. 14 Plots of $\mathrm{Zr}$ versus $\mathrm{V}$ for the different Erzgebirge units and subunits. In order to obtain a better overview, mixedspectrum results in Raman spot analysis are plotted as rutiles. Dotted lines show approximate maximum unit metamorphic temperatures as found by Schmädicke and Müller (2000), Mingram and Rötzler (1999), Rötzler et al. (1998), Massonne et al. (1998), and Willner et al. (1997), back-calculated to $\mathrm{Zr}$ contents by the calibration of Tomkins et al. (2007). Anatase analyses from Kirchberg granite $(K G)$ are shown for comparison
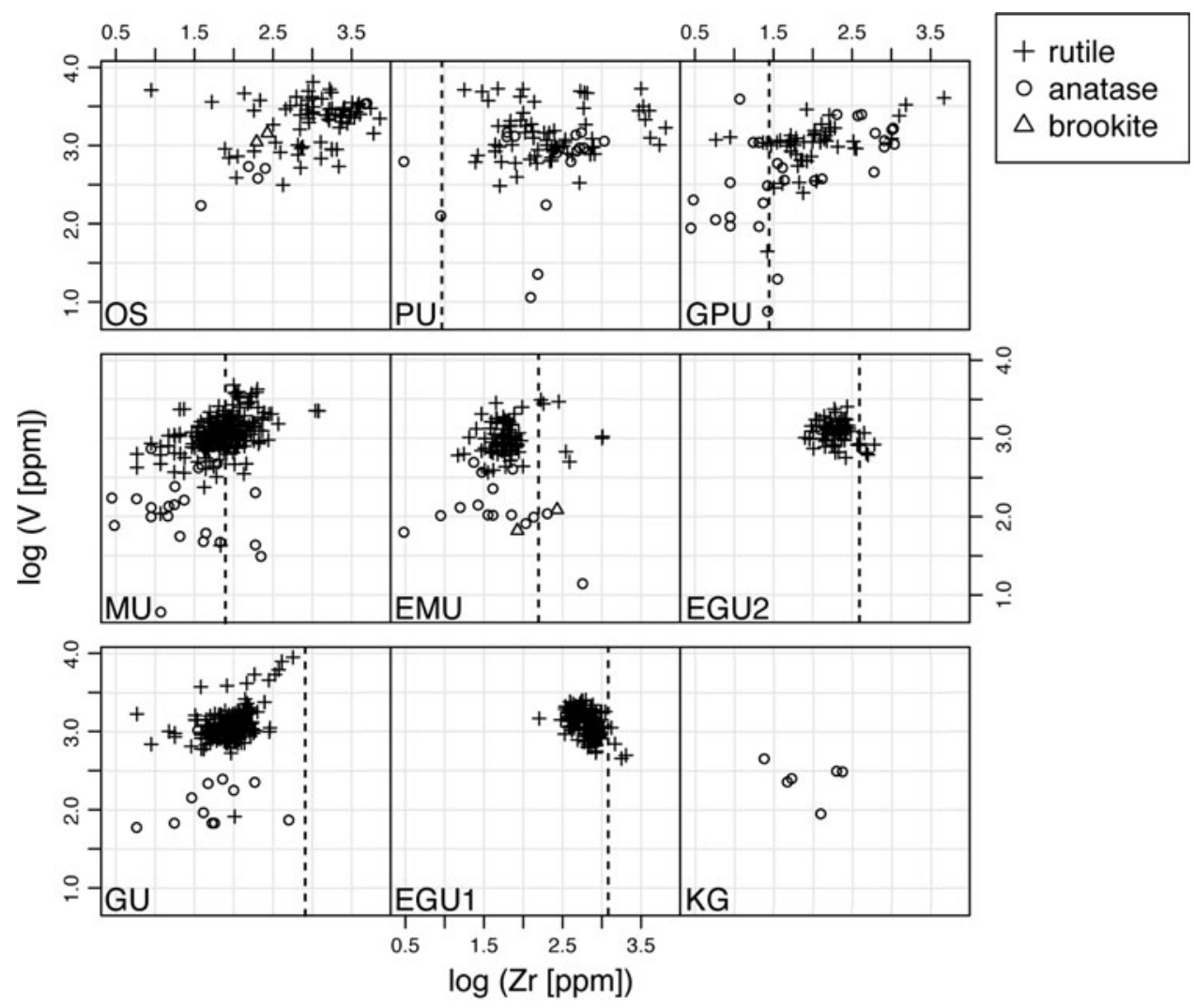

Table 8 Prior probabilities from HUY, WAR, and the single crystals (compilation) and all Erzgebirge samples (data from Tables 5 and 7) in comparison

\begin{tabular}{llll}
\hline & Anatase & Brookite & Rutile \\
\hline Compilation & 0.33 & 0.05 & 0.62 \\
Erzgebirge & 0.04 & 0.01 & 0.95 \\
\hline
\end{tabular}

For a classification of rutile samples using geochemical data, correct-classification rates for rutile of $>97 \%$ (single crystals, HUY-1, and WAR-9), 95\% (Erzgebirge samples) and, applying prior probabilities from a natural sample set, nearly $100 \%$ (samples from the Alps, Syros, and Mexico) were found, implying that identification of $\mathrm{TiO}_{2}$ polymorphs by TE contents works well. Additionally, it goes hand in hand with general TE characterization by electron microprobe.

During in situ recrystallization of rutile to anatase, anatase maintains the largest part of rutiles TE budget. An equilibration of anatase TE contents takes place after complete recrystallization and/or by anatase nucleation in another place. Differences in $\mathrm{Zr}$ characteristics of anatase point out that pressure and temperature settings play only a minor role in rutile re-equilibration and recrystallization processes of rutile to anatase. More important are mineral assemblage characteristics or fluid occurrence or composition. The mere occurrence of anatase, on the other hand, is controlled by the metamorphic gradient and, supposedly, whole rock chemistry.

Acknowledgments We thank Burkhard Schmidt and Andreas Kronz for help on Raman and EMP analyses and for fruitful discussions. Lutz Nasdala is thanked for helpful suggestions. E. Bruce Watson, Timothy L. Grove, and an unknown reviewer provided very constructive reviews and comments. The Geowissenschaftliches Museum und Sammlungen der Universität Göttingen is thanked for providing samples. Financial support is acknowledged from the Deutsche Forschungsgemeinschaft (EY 23/10-2 and ZA 285/2-1).

Open Access This article is distributed under the terms of the Creative Commons Attribution Noncommercial License which permits any noncommercial use, distribution, and reproduction in any medium, provided the original author(s) and source are credited.

\section{References}

Armstrong JT (1995) A package of correction programs for the quantitative electron microbeam X-ray analysis of thick polished materials, thin films and particles. Microbeam Anal 4:177-200

Bastin G, Vanloo F, Vosters P, Vrolijk J (1984a) A correction procedure for characteristic fluorescence in microprobe analysis near phase boundaries. J Phys 45(NC-2):43-46

Bastin G, Vanloo F, Vosters P, Vrolijk J (1984b) An iterative procedure for the correction of secondary fluorescence effects in electron-probe microanalysis near phase boundaries. Spectrochim Acta Part B At Spectrosc 39(12):1517-1522 
Dachille F, Simons PY, Roy R (1968) Pressure-temperature studies of anatase, brookite, rutile and $\mathrm{TiO}_{2}$ (II). Am Mineral 53:1929-1939

Dallmeyer RD, Franke W, Weber K (eds) (1995) Pre-permian geology of Central and Eastern Europe. Springer, Berlin

Dalton J, Lane S (1996) Electron microprobe analysis of Ca in olivine close to grain boundaries: the problem of secondary X-ray fluorescence. Am Mineral 81(1-2):194-201

Grzmil B, Rabe M, Kic B, Lubkowski K (2007) Influence of phosphate, potassium, lithium, and aluminium on the anataserutile phase transformation. Ind Eng Chem Res 46(4):1018-1024

Hwang SL, Shen P, Chu HT, Yui TF (2000) Nanometer-size- $\mathrm{PbO}_{2}-$ type $\mathrm{TiO}_{2}$ in garnet: a thermobarometer for ultrahigh-pressure metamorphism. Science 288(5464):321-324

Jamieson JC, Olinger B (1969) Pressure-temperature studies of anatase, brookite, rutile and $\mathrm{TiO}_{2}$ (II): a discussion. Am Mineral 54:1477-1481

Kretz R (1983) Symbols for rock forming minerals. Am Mineral 68(1-2):277-279

Luvizotto GL, Zack T (2009) $\mathrm{Nb}$ and $\mathrm{Zr}$ behavior in rutile during high-grade metamorphism and retrogression: an example from the Ivrea-Verbano Zone. Chem Geol 261(3-4):303-317

Luvizotto GL, Zack T, Triebold S, von Eynatten H (2009) Rutile occurrence and trace element behavior in medium-grade metasedimentary rocks: example from the Erzgebirge, Germany. Mineral Petrol 97(3-4):233-249

Massonne HJ, Bernhardt HJ, Dettmar D, Kessler E, Medenbach O, Westphal T (1998) Simple identification and quantification of microdiamonds in rock thin-sections. Eur $\mathrm{J}$ Mineral 10(3):497-504

Meinhold G, Anders B, Kostopoulos D, Reischmann T (2008) Rutile chemistry and thermometry as provenance indicator: an example from Chios Island, Greece. Sediment Geol 203(1-2):98-111

Mezger K, Hanson GN, Bohlen SR (1989) High-precision U-Pb ages of metamorphic rutile: application to the cooling history of highgrade terranes. Earth Planet Sci Lett 96:106-118

Mingram B (1998) The Erzgebirge, Germany, a subducted part of northern Gondwana: geochemical evidence for repetition of early Paleozoic metasedimentary sequences in metamorphic thrust units. Geol Mag 135(6):785-801

Mingram B, Rötzler K (1999) Geochemische, petrologische und geochronologische Untersuchungen im ErzgebirgskristallinRekonstruktion eines Krustenstapels. Schriftenreihe fuer Geowissenschaften 9:80

Rötzler K, Schumacher R, Maresch WV, Willner AP (1998) Characterization and geodynamic implications of contrasting metamorphic evolution in juxtaposed high-pressure units of the western Erzgebirge (Saxony, Germany). Eur J Mineral 10(2):261-280

Schmädicke E, Müller WF (2000) Unusual exsolution phenomena in omphacite and partial replacement of phengite by phlogopite + kyanite in an eclogite from the Erzgebirge. Contrib Mineral Petrol 139:629-642

Sembaev D, Ivanovskaya F, Saurambaeva L, Yugay O, Mikhailovskaya T (2008) Effect of oxides of the IV and VI group metals on the polymorphic transformation of anatase into rutile. React Kinet Catal Lett 93(2):211-217

Smith SJ, Stevens R, Liu S, Li G, Navrotsky A, Boerio-Goates J, Woodfield BF (2009) Heat capacities and thermodynamic functions of $\mathrm{TiO}_{2}$ anatase and rutile: analysis of phase stability. Am Mineral 94(2-3):236-243
Spear FS, Wark DA, Cheney JT, Schumacher JC, Watson EB (2006) $\mathrm{Zr}$-in-rutile thermometry in blueschists from Sifnos, Greece. Contrib Mineral Petrol 152(3):375-385

Stockli DF, Wolfe MR, Blackburn TJ, Zack T, Walker JD, Luvizotto GL (2007) He diffusion and (U-Th)/He thermochronology of rutile. In: American geophysical union, Fall meeting, pp V23C-1548

Tomkins HS, Powell R, Ellis DJ (2007) The pressure dependence of the zirconium-in-rutile thermometer. J Metamorphic Geol 25(6):703-713

Triebold S, von Eynatten H, Luvizotto GL, Zack T (2007) Deducing source rock lithology from detrital rutile geochemistry: an example from the Erzgebirge, Germany. Chem Geol 244(3-4):421-436

van den Boogart KG, Tolosana-Delgado R, Bren M (2006) Concepts for handling zeroes and missing values in compositional data. In: Pirard E, Dassargues A, Havenith $\mathrm{H}$ (eds) Proceedings of IAMG'06-the XI annual conference of the international association for mathematical geology. University of Liège, Belgium

von Eynatten H, Tolosana-Delgado R, Triebold S, Zack T (2005) Interactions between grain size and composition of sediments: two examples. In: Proceedings CoDaWork05-2nd compositional data analysis workshop, Girona, 19-21 Oct 2005

Vry JK, Baker JA (2006) LA-MC-ICPMS Pb-Pb dating of rutile from slowly cooled granulites: confirmation of the high closure temperature for $\mathrm{Pb}$ diffusion in rutile. Geochim Cosmochim Acta 70(7):1807-1820

Vry J, Baker J, Waight $\mathrm{T}$ (2003) In situ $\mathrm{Pb}-\mathrm{Pb}$ dating of rutile from slowly cooled granulites by La-Mc-ICP-MS: confirmation of the high closure temperature $\left(>600^{\circ} \mathrm{C}\right)$ for $\mathrm{Pb}$ diffusion in rutile. Geophys Res Abstr 5(10199)

Wark DA, Watson EB (2006) TitaniQ: a titanium-in-quartz geothermometer. Contrib Mineral Petrol 152:743-754

Watson E, Wark D, Thomas J (2006) Crystallization thermometers for zircon and rutile. Contrib Mineral Petrol 151(4):413-433

Weltje G, von Eynatten H (2004) Quantitative provenance analysis of sediments: review and outlook. Sediment Geol 171(1-4):1-11

Willner AP, Roetzler K, Maresch WV (1997) Pressure-temperature and fluid evolution of quartzo-feldspathic metamorphic rocks with a relic high-pressure, granulite-facies history from the Central Erzgebirge (Saxony, Germany). J Petrol 38(3):307-336

Willner AP, Krohe A, Maresch MV (2000) Interrelated P-T-t-d paths in the Variscan Erzgebirge dome (Saxony, Germany): constraints on the rapid exhumation of high-pressure rocks from the root zone of a collisional orogen. Int Geol Rev 42(1):64-85

Withers AC, Essene EJ, Zhang YX (2003) Rutile/TiO ${ }_{2}$ II phase equilibria. Contrib Mineral Petrol 145(2):199-204

Yang P, Rivers T (2001) Chromium and manganese zoning in pelitic garnet and kyanite: spiral, overprint, and oscillatory (?) zoning patterns and the role of growth rate. J Metamorphic Geol 19:455-474

Zack T, Luvizotto GL (2006) Application of rutile thermometry to eclogites. Mineral Petrol 88(1):69-85

Zack T, von Eynatten H, Kronz A (2004a) Rutile geochemistry and its potential use in quantitative provenance studies. Sediment Geol $171: 37-58$

Zack T, Moraes R, Kronz A (2004b) Temperature dependence of Zr in rutile: empirical calibration of a rutile thermometer. Contrib Mineral Petrol 148(4):471-488 